Науковий вісник : Державне управління № 4(10) 2021

УДК 378:351.7(477)

Андреєв Сергій

ORCID iD 0000-0002-8231-8105

e-mail: andreyev.doc@gmail.com

\title{
БЕЗПЕКОВА СКЛАДОВА ФАХОВОЇ КОМПЕТЕНТНОСТІ ЗДОБУВАЧІВ ВИЩОЇ ОСВІТИ 3 ПУБЛІЧНОГО УПРАВЛІННЯ ТА АДМІНІСТРУВАННЯ
}

\author{
https://doi.org/10.33269/2618-0065-2021-4(10)-5-21
}

Анотація. У статті наведено результати дослідження сучасного стану безпекової освітньої компоненти у змісті професійної підготовки здобувачів вищої освіти за спеціальністю 281 «Публічне управління та адміністрування» (на прикладі другого (магістерського) рівня) в Україні. Акцентовано увагу на нагальній для нашої крани потребі цільової професійної підготовки державно-управлінських кадрів, компетентних у питаннях національної безпеки. Розглянуто процес становлення спеціальності «Державне управління у сфері національної безпеки» в межах галузі знань 1501 Державне управління протягом 2002-2015 рр. Проведено вибірковий аналіз магістерських програм зі спеціальності 281 «Публічне управління та адміністрування» деяких закладів вищої освіти на предмет наявності обов'язкових та вибіркових навчальних дисциплін, спрямованих на формування у студентів безпекової складової фахової компетентності. Обгрунтовано пропозиції щодо переліку спеціальних (фахових, предметних) компетентностей здобувачів вищої освіти за вказаною спеціальністю в рамках магістерської програми «Державне управління у сфері національної безпеки», а також стосовно переліку обов'язкових компонент відповідної програми. Зроблено такі висновки: включення освітніми закладами в магістерські програми зі спеціальності 281 «Публічне управління та адміністрування» навчальних дисциплін 3 питань національної безпеки, державного управління у цій сфері, має фрагментарний характер, через що у змісті цих програм розмивається безпекова компонента; відсутність бюджетних магістерських програм зі спеціальності 256 «Національна безпека», а також з питань державного управління у сфері національної безпеки за спеціальністю 281 «Публічне управління та адміністрування» свідчать про брак системного підходу до вирішення проблем професійного навчання управлінських кадрів для сфери національної безпеки. Обгрунтовано пропозицію щодо необхідності розробки та впровадження у навчальний процес магістерських програм «Державне управління у сфері національної безпеки» зі спеціальності 281 «Публічне управління та адміністрування», фінансування таких програм за рахунок коштів державного бюджету.

Ключові слова: безпека держави, безпека людини, безпека суспільства, безпекова складова фахової компетентності, вища освіта, державне управління, компетентність, національна безпека, професійна підготовка, публічне адміністрування, публічне управління. 
Постановка проблеми. У чинній Стратегії національної безпеки України 2020 р. наведено перелік актуальних поточних i прогнозованих загроз національній безпеці (далі - НБ) та національним інтересам України 3 урахуванням зовнішньополітичних та внутрішніх умов [1]. Різноманітний характер та широкий спектр цих загроз переконливо доводить, що їхня ефективна нейтралізація можлива тільки шляхом створення в нашій країні ефективної системи державного управління.

У свою чергу, вирішення цього надскладного завдання потребує, зокрема, цільової якісної підготовки державноуправлінських кадрів, які мають формувати відповідну систему та виступати головною рушійною силою іiі розвитку. Невипадково у новій Стратегії реформування державного управління України на 2022-2025 рр. зазначається, що невід’ємним компонентом модернізації державного управління $€$ підвищення якості професійного навчання державних службовців та посадових осіб місцевого самоврядування, а також те, що зміст цього навчання не повною мірою відповідає потребам у такому навчанні [2].

Останніми роками в Україні відбулись радикальні ідеологічні та інституціональні зміни в системі професійної підготовки державно-управлінських кадрів, що полягають, насамперед, у запровадженні з 2015-2016 рр. спеціальності та галузі знань «Публічне управління та адміністрування» (далі 281 ПУА) на заміну галузі знань «Державне управління», а також у припиненні впродовж 2021 р. як юридичної особи Національної академії державного управління при Президентові України (далі - НАДУ) та чотирьох іiі регіональних інститутів (Дніпропетровського, Львівського, Одеського, Харківського) шляхом приєднання до інших закладів вищої освіти (докл. див.: [3-5]).

Наведені вище обставини актуалізують дослідження питання про те, яким чином вплинули згадані зміни на формування спеціальних (фахових, предметних) безпекових компетентностей у здобувачів вищої освіти за спеціальністю ПУА в Україні. 
Припускаємо, що ліквідація у квітні 2015 р. галузі знань 1501 Державне управління, а також демонополізація системи професійної підготовки управлінських кадрів шляхом припинення НАДУ як юридичної особи та залучення до цієї підготовки інших численних освітніх закладів, не могли не позначитися на якості професійного навчання здобувачів вищої освіти за спеціальністю 281 ПУА, в частині їхньої підготовки у сфері безпеки людини, суспільства та держави. Ця гіпотеза зумовила вибір мети цієї праці.

Аналіз останніх досліджень і публікацій. Різноманітним аспектам професійної підготовки управлінських кадрів органів державної влади, органів місцевого самоврядування України присвячено велику кількість наукових праць. Відзначимо вагомий науковий доробок у цій царині вітчизняних науковців: О. Васильєвої, К. Ващенка, Н. Гончарук, В. Гошовської, М. Іжи, В. Лугового, А. Михненка, Т. Мотренка, Р. Науменко, С. Серьогіна, С. Хаджирадєвої.

Для формування безпекової освітньої компоненти у змісті магістерських програм за спеціальністю 281 ПУА визначальну роль відіграють наукові праці 3 питань НБ та державного управління в цій сфері. Так, питанням системного осмислення феномену НБ та розвитку відповідної теорії присвячені праці О. Власюка [6], В. Горбуліна [7; 8], Ю. Даника [9], О. Дзьобаня [10], А. Качинського [11], В. Ліпкана [12], Г. Ситника [13-15].

Окрім цих вчених, суттєвий внесок у формування теоретичних засад державного управління у сфері НБ внесли В. Абрамов [15], В. Смолянюк [15], В. Богданович [16], А. Семенченко [16;17]. У контексті розвитку теоретичних та методологічних засад НБ важливе значення мають праці С. Бабуріна [18], М. Дзлієва [18; 19], А. Урсула [18; 19], А. Романовича [19], А. Возженікова [20].

Питання модернізації системи підготовки фахівців у сфері НБ України розглядались у працях Р. Марутян [21; 22].

Являє чималий інтерес стаття американських дослідників Д. Рамсі, I. Ренди-Таналі, в якій автори грунтовно проаналізували зміст професійних програм підготовки фахівців у сфері безпеки, а також підходи до розробки кваліфікаційних 
освітніх стандартів для академічних програм внутрішньої безпеки у США [23].

Відповідно до проведеного аналізу наукових праць доведено, що після появи у національному освітньому просторі спеціальності та галузі знань ПУА (2015-2016рр.), проблематиці щодо змісту та обсягу безпекових компетентностей управлінських кадрів, а також підходам до розробки освітньо-професійних (далі - ОПП), освітньонаукових програм 3 питань державного управління у сфері НБ приділяється недостатньо уваги.

Метою статті $\epsilon$ оцінка стану безпекової освітньої компоненти у змісті професійної підготовки здобувачів вищої освіти за спеціальністю ПУА (на прикладі другого (магістерського) рівня) в Україні.

Методи дослідження. У статті використано низку методів: історичний (ретроспективний) аналіз, контент-аналіз, дедукції, формалізації та синтезу. За допомогою методу історичного (ретроспективного) аналізу досліджено процес становлення спеціальності «Державне управління у сфері національної безпеки» в межах галузі знань 1501 «Державне управління». Метод контент-аналізу використано під час дослідження джерельної бази 3 тематики статті, а також у процесі оцінки змісту магістерських програм закладів вищої освіти зі спеціальності 281 ПУА щодо наявності компонент, спрямованих на формування у здобувачів освіти безпекової складової фахової компетентності. Методи дедукції, формалізації та синтезу застосовано при обгрунтуванні пропозицій щодо спеціальних (фахових, предметних) компетентностей здобувачів вищої освіти за спеціальністю 281 ПУА в рамках магістерської програми «Державне управління у сфері національної безпеки», переліку обов'язкових компонент відповідної освітньої програми, формулюванні висновків та інших пропозицій.

Виклад основного матеріалу. Дослідження порушеного у цій статті проблемного питання доцільно почати 3 того, що 28 вересня 2000 р. у складі НАДУ було створено кафедру національної безпеки (далі - кафедра НБ), а у 2002 р. - 
запроваджено спеціалізацію «Державне управління у сфері національної безпеки» (в межах спеціальності «Державне управління») [24].

У 2008 р. колективом згаданої кафедри були обгрунтовані концептуальні засади запровадження в Україні нової спеціальності - «Державне управління у сфері національної безпеки» (освітньо-кваліфікаційний рівень - «магістр»), а також затверджено відповідну освітню програму. У межах спеціальності було передбачено такі спеціалізації: «Стратегічне управління у сфері національної безпеки», «Державні механізми забезпечення політичної безпеки», «Державні механізми забезпечення економічної безпеки» [24].

На нормативно-правовому рівні ідею щодо введення спеціальності «Державне управління у сфері національної безпеки» до складу напряму підготовки 1501 Державне управління було реалізовано Міністерством освіти і науки України (далі - МОН) у 2008 р. шляхом видання наказу «Про затвердження змін до Переліку напрямів та спеціальностей, за якими здійснюється підготовка фахівців у вищих навчальних закладах за відповідними освітньо-кваліфікаційними рівнями», затвердженого постановою Кабінету Міністрів України (далі КМУ) від 24.05.1997 № 507» від 05.05.2008 № 374. Згідно з цим наказом напрям підготовки 1501 Державне управління доповнювався десятьма спеціальностями освітньокваліфікаційного рівня «магістр», зокрема спеціальністю 8.150103 Державне управління у сфері національної безпеки [25] (код цієї спеціальності змінювався: у 2010 р. - 8.15010006, a у 2011 p. - 8.15010004).

Необхідно зазначити, що в період 2000-2015 pp. у системі професійного навчання державних службовців та посадових осіб органів місцевого самоврядування України фактично було сформовано унікальну інституційну підсистему підготовки магістрів за спеціальністю «Державне управління у сфері національної безпеки», на чолі якої перебувала кафедра НБ НАДУ, а іншими складовими елементами виступали аналогічні їй за профілем та назвою кафедри, сформовані у складі регіональних інститутів НАДУ. 
Упродовж 2010-2017 pp. науково-педагогічним складом згаданої кафедри НАДУ за участю інших кафедр та провідних фахівців України 3 питань НБ було підготовлено майже 500 магістрів державного управління у сфері НБ [24]. Також не можна не відзначити вагомі результати навчально-методичної та наукової роботи кафедри НБ НАДУ стосовно підготовки підручників, навчальних посібників, інших методичних матеріалів, виконання науково-дослідних робіт, підготовки монографій, дисертацій тощо (докл. див.: [24]).

Однак, згідно з постановою КМУ від 29.04.2015 № 266 професійна підготовка державно-управлінських кадрів за спеціальністю «Державне управління у сфері національної безпеки» в Україні була припинена у зв'язку зі скасуванням у повному складі галузі знань 1501 Державне управління [3]. Відповідне управлінське рішення Уряду, на нашу думку, порушило всю попередню логіку історії становлення концептуальних, ідеологічних та інституційних засад цієї підготовки у незалежній Україні, створивши передумови для певного вакууму - безсистемності та фрагментарності формування безпекової складової фахових компетентностей у майбутніх управлінських кадрів державного сектору.

Як ми вже згадували вище, протягом 2015-2016 рр. в нашій країні було запроваджено спочатку спеціальність - ПУА (2015 р.), а згодом галузь знань - ПУА (2016 р.). Здобувати вищу освіту за спеціальністю ПУА відтоді можна як за першим (бакалаврським), так і за другим (магістерським) рівнем вищої освіти.

За даними ЄДЕБО станом на 10.10.2021 у нашій країні 112 закладів вищої освіти різної форми власності пропонують магістерські програми за спеціальністю 281 ПУА [26]. Серед цього масиву програм немає жодної освітньої (освітньопрофесійної чи то освітньо-наукової програми), у назві якої б використовувався термін «національна безпека». Про наявність аутентичних фахових магістерських програм «Державне управління у сфері національної безпеки» або аналогів у межах вказаної спеціальності годі й казати. Разом 3 тим, серед конкурсних пропозицій 2021 р. варто відзначити небюджетні ОПП «Публічне управління та адміністрування у сфері 
цивільної безпеки» Національного університету цивільного захисту України, а також ОПП «Управління у сфері цивільного захисту» Інституту державного управління та наукових досліджень 3 цивільного захисту [26].

У ч. 5 ст. 9 Закону України «Про вищу освіту» закріплено, що заклади вищої освіти (наукові установи) самостійно розробляють і затверджують освітні програми з урахуванням вимог до відповідного рівня вищої освіти, встановлених законодавством та стандартами вищої освіти [27].

Стандарт вищої освіти за спеціальністю 281 ПУА галузі знань 28 ПУА для другого (магістерського) рівня вищої освіти затверджено наказом МОН від 04.08.2020 № 1001 (далі Стандарт) та введено в дію з 2020/2021 навчального року [28]. Цей нормативний документ містить 10 спеціальних (фахових, предметних) компетентностей випускника, в тому числі таку компетентність як «здатність здійснювати професійну діяльність з урахуванням потреб забезпечення національної безпеки України», а також 12 результатів навчання, серед яких $€$ такий пункт: «знати основні засади національної безпеки та уміти попереджати й нейтралізувати виклики i загрози національним інтересам України в межах своєї професійної компетенції» [28].

Таким чином, заклади вищої освіти при затвердженні та впровадженні у навчальний процес освітніх програм підготовки здобувачів вищої освіти за спеціальністю 281 ПУА для другого (магістерського) рівня зобов'язані, серед іншого, забезпечувати формування відповідної компетентності та результату навчання.

Для досягнення поставленої у статті мети методом випадкової вибірки ми провели аналіз магістерських ОПП 2020-2021 pp. зі спеціальності 281 ПУА деяких закладів вищої освіти щодо наявності освітніх компонент (навчальних дисциплін), спрямованих на формування у здобувачів освіти безпекових компетентностей (передусім, компетенцій у сфері НБ України) (табл. 1). Використовувалась інформація, наведена на вебсайтах цих освітніх закладів у мережі Інтернет, де розміщені відповідні програми (або їхні профілі) чи навчальні 


\section{плани. Брались до уваги навчальні дисципліни, в назві яких використовуються терміни «безпека», «національна безпека».}

\section{Таблицяя 1 - Освітні компоненти (навчальні дисципліни), спрямовані на формування у здобувачів другого (магістерського) рівня вищої освіти за спеціальністю 281 ПУА безпекової складової фахової компетентності}

\begin{tabular}{|c|c|c|}
\hline \multirow[t]{2}{*}{$\begin{array}{l}\text { № } \\
\text { 3/II }\end{array}$} & \multicolumn{2}{|c|}{$\begin{array}{c}\text { Найменування закладу вищої освіти (випадкова вибірка), освітньої програми } \\
\text { за спеціальністю ПУА, навчальних дисциплін з безпекової тематики }\end{array}$} \\
\hline & Обов'язкові компоненти & Вибіркові компоненти \\
\hline 1. & \multicolumn{2}{|c|}{$\begin{array}{l}\text { Одеський національний політехнічний університет } \\
\text { (ОПП "Публічне управління та адміністрування") }\end{array}$} \\
\hline & - & $\begin{array}{l}\text { Безпека технічних систем } \\
\text { Управління ризиками } \\
\text { Обліково-аналітичне забезпечення фінансово-економічної } \\
\text { безпеки }\end{array}$ \\
\hline \multirow[t]{2}{*}{2.} & \multicolumn{2}{|c|}{$\begin{array}{c}\text { Комунальний заклад вищеї освіти “Дніпровська академія неперервної освіти } \\
\text { “Дніпропетровської обласної ради” } \\
\text { (ОПП “Публічне управління та адміністрування”) }\end{array}$} \\
\hline & - & не конкретизовані у програмі \\
\hline \multirow[t]{2}{*}{3.} & \multicolumn{2}{|c|}{$\begin{array}{c}\text { Донецький національний медичний університет } \\
\text { (ОПП “Публічне управління та адміністрування у галузі охорони здоров’я”) }\end{array}$} \\
\hline & - & $\begin{array}{l}\text { Управління сферою охорони здоров’я у надзвичайних } \\
\text { ситуаціях } \\
\text { Медичний захист населення і територій від надзвичайних } \\
\text { ситуацій }\end{array}$ \\
\hline \multirow[t]{2}{*}{4.} & \multicolumn{2}{|c|}{$\begin{array}{c}\text { Вищий навчальний заклад “Київський університет ринкових відносин” } \\
\text { (ОПП “Публічне управління та адміністрування”) }\end{array}$} \\
\hline & $\begin{array}{l}\text { Глобалізація та політика } \\
\text { національної безпеки }\end{array}$ & Антикризове управління \\
\hline \multirow[t]{2}{*}{5.} & \multicolumn{2}{|c|}{$\begin{array}{l}\text { Приватний заклад вищої освіти “Киӥвський міжннародний університет” } \\
\text { (Освітньо-наукова програма "Публічне управління та адміністрування") }\end{array}$} \\
\hline & - & $\begin{array}{l}\text { Проблеми національної та регіональної безпеки } \\
\text { Інформаційна безпека та ризик-менеджмент }\end{array}$ \\
\hline \multirow[t]{2}{*}{6.} & \multicolumn{2}{|c|}{$\begin{array}{c}\text { Національний технічний університет Украӥни “Київський політехнічний } \\
\text { інститут імені Ігоря Сікорського” } \\
\text { (ОПП “Публічне адміністрування та електронне урядування”) }\end{array}$} \\
\hline & $\begin{array}{l}\text { Основи національної } \\
\text { безпеки }\end{array}$ & не конкретизовані у програмі \\
\hline \multirow[t]{2}{*}{7.} & \multicolumn{2}{|c|}{$\begin{array}{c}\text { Національна медична академія післядипломної освіти ім. П. Л. Шупика } \\
\text { (ОПП “Публічне управління та адміністрування") }\end{array}$} \\
\hline & $\begin{array}{l}\text { Україна в геополітичному } \\
\text { просторі та системі } \\
\text { міжнародної безпеки }\end{array}$ & - \\
\hline \multirow[t]{2}{*}{8.} & \multicolumn{2}{|c|}{$\begin{array}{c}\text { Національний університет цивільного захисту Украӥни } \\
\text { (ОПП “Публічне управління та адміністрування") }\end{array}$} \\
\hline & - & - \\
\hline 9. & \multicolumn{2}{|c|}{$\begin{array}{l}\text { Національний університет “Одеська юридична академія” } \\
\text { (ОПП "Публічне управління та адміністрування”) }\end{array}$} \\
\hline
\end{tabular}




\section{Науковий вісник : Державне управління № 4(10) 2021}

\begin{tabular}{|c|c|c|}
\hline \multirow[t]{3}{*}{$\begin{array}{l}\text { № } \\
3 / \text { II }\end{array}$} & \multicolumn{2}{|c|}{$\begin{array}{c}\text { Найменування закладу вищої освіти (випадкова вибірка), освітньої програми } \\
\text { за спеціальністю ПУА, навчальних дисциплін з безпекової тематики }\end{array}$} \\
\hline & Обов'язкові компоненти & Вибіркові компоненти \\
\hline & $\begin{array}{l}\text { Актуальні проблеми } \\
\text { безпеки у європейському } \\
\text { та євроатлантичному } \\
\text { вимірі }\end{array}$ & $\begin{array}{l}\text { Інформаційні війни } \\
\text { Кібербезпека } \\
\text { Антикризове управління }\end{array}$ \\
\hline \multirow[t]{2}{*}{10.} & \multicolumn{2}{|c|}{$\begin{array}{c}\text { Національний університет біоресурсів та природокористування України } \\
\text { (ОПП “Публічне управління та адміністрування”) }\end{array}$} \\
\hline & $\begin{array}{l}\text { Державне управління } \\
\text { національною безпекою }\end{array}$ & - \\
\hline \multirow[t]{2}{*}{11.} & \multicolumn{2}{|c|}{$\begin{array}{c}\text { Полтавська держсавна аграрна академія } \\
\text { (ОПП “Зв'язки } 3 \text { громадськістю”) }\end{array}$} \\
\hline & - & не конкретизовані у програмі \\
\hline \multirow[t]{2}{*}{12.} & \multicolumn{2}{|c|}{$\begin{array}{c}\text { Національний університет “Полтавська політехніка імені Юрія Кондратюка” } \\
\text { (ОПП “Публічне управління та адміністрування”) }\end{array}$} \\
\hline & $\begin{array}{l}\text { Євроінтеграція, } \\
\text { міжнародне публічне } \\
\text { управління та безпека }\end{array}$ & - \\
\hline \multirow[t]{2}{*}{13.} & \multicolumn{2}{|c|}{$\begin{array}{c}\text { Украӥнський держсавний університет залізничного транспорту } \\
\text { (ОПП “Публічне управління та адміністрування”) }\end{array}$} \\
\hline & $\begin{array}{l}\text { Євроінтеграція, } \\
\text { міжнародне публічне } \\
\text { управління та безпека }\end{array}$ & не конкретизовані у програмі \\
\hline \multirow[t]{2}{*}{14.} & \multicolumn{2}{|c|}{$\begin{array}{c}\text { Харківський національний університет будівництва та архітектури } \\
\text { (ОПП “Публічне управління та адміністрування") }\end{array}$} \\
\hline & - & Глобалізація і політика національної безпеки \\
\hline \multirow[t]{2}{*}{15.} & \multicolumn{2}{|c|}{$\begin{array}{c}\text { Національний університет “Чернігівська політехніка” } \\
\text { (ОПП “Державна служба”) }\end{array}$} \\
\hline & $\begin{array}{l}\text { Цивільний захист та } \\
\text { охорона праці в галузі }\end{array}$ & $\begin{array}{l}\text { Антикризове управління в органах державної влади та } \\
\text { місцевого самоврядування }\end{array}$ \\
\hline \multirow[t]{2}{*}{16.} & \multicolumn{2}{|c|}{$\begin{array}{c}\text { Тернопільський національний технічний університет імені Івана Пулюя } \\
\text { (ОПП “Публічне управління та адміністрування”) }\end{array}$} \\
\hline & - & - \\
\hline \multirow[t]{2}{*}{17.} & \multicolumn{2}{|c|}{$\begin{array}{c}\text { Таврійський державний агротехнологічний університет імені Дмитра Моторного } \\
\text { (ОПП “Публічне управління та адміністрування") }\end{array}$} \\
\hline & - & не конкретизовані у програмі \\
\hline
\end{tabular}

А також інші терміни, семантично близькі до безпекової сфери: «війна», «загроза», «захист», «криза», «оборона», «ризик» тощо.

Аналіз даних, наведених у табл. 1, надає можливість констатувати:

\section{1. Лише 3 із 17 досліджених ОПП містять серед} обов'язкових компонент навчальні дисципліни, присвячені безпосередньо тематиці НБ (п.п. 4, 6, 10 табл. 1). Інші ж 
дисципліни, в назві яких використовуються терміни «безпека», «захист», скоріше за все лише частково можуть розкривати окремі питання НБ України (п.п. 7, 9, 15 табл. 1). Тобто, переважна більшість досліджених освітніх програм за спеціальністю ПУА не включає обов'язкових компонент 3 питань НБ. Хоча можна цілком припустити, що інші навчальні дисципліни (як, наприклад, «Стратегічне управління», «Антикризове управління») можуть включати окремі модулі або теми з цих питань.

2. Питома вага компонент 3 основ НБ у категорії вибіркових навчальних дисциплін $\epsilon$ ще меншою, ніж в обов'язкових, оскільки освітні програми тільки 2 з 17 закладів вищої освіти містять згадані компоненти (п.П. 5, 14 табл. 1). Вибіркові дисципліни 3 різних аспектів безпеки, які ми включили до групи таких, що можуть формувати безпекові компетентності здобувачів освіти за спеціальністю ПУА та містяться в магістерських програмах інших закладів (п. п. 1, 3, 4, 9, 15 табл. 1), можна зарахувати до цієї групи 3 певними застереженнями, зважаючи на їхню специфіку.

Якщо подивитись на проблему професійної підготовки управлінських кадрів для сфери НБ України ширше (не суто в рамках можливостей такої підготовки в межах галузі знань 28 ПУА), то слід акцентувати увагу на тому, що чинний Перелік галузей знань і спеціальностей, за яким здійснюється підготовка здобувачів вищої освіти, затверджений постановою КМУ від 29.04.2015 № 266 (далі - Перелік галузей знань і спеціальностей), містить спеціальність 256 Національна безпека (за окремими сферами забезпечення і видами діяльності), яка перебуває у складі галузі знань 25 Воєнні науки, національна безпека, безпека державного кордону [26]. Водночас, у Переліку галузей знань і спеціальностей наведено примітку, що такий вид (види) діяльності затверджується відповідним державним органом, який забезпечує виконання завдань у сфері НБ, за погодженням з МОН [26].

На сьогодні не затверджено ні стандарти вищої освіти зі спеціальності 256 Національна безпека, ні вказаний Перелік окремих сфер забезпечення і видів діяльності у сфері НБ, що не сприяє широкому поширенню освітніх програм магістерського 
та інших рівнів з цієї спеціальності. Так, за даними ЄДЕБО станом на 10.10.2021 в Україні лише 3 заклади вищої освіти пропонують вступникам програми освітнього рівня «магістр» за спеціальністю 256 Національна безпека: Державний університет «Житомирська політехніка» (ОПП «Національна безпека (за окремими сферами забезпечення і видами діяльності)»), Національна академія Служби безпеки України (ОПП «Організація захисту інформації з обмеженим доступом», ОПП «Кіберзахист у сфері інформаційних технологій та кіберпростору»), Національний університет «Острозька академія» (ОПП «Національна безпека (за окремими сферами забезпечення і видами діяльності)»). При цьому всі наведені пропозиції є небюджетними [27].

Ураховуючи викладене вважаємо, що в Україні існує нагальна потреба розробки та впровадження у навчальний процес якісних магістерських освітніх програм «Державне управління у сфері національної безпеки» зі спеціальності 281 ПУА.

Однойменна магістерська програма, крім компетентностей, визначених у відповідному освітньому стандарті, на нашу думку, може включати додаткові спеціальні (фахові, предметні) компетентності здобувачів вищої освіти щодо здатності:

обгрунтовано визначати стратегічні цілі та пріоритети діяльності органів державної влади, органів місцевого самоврядування, їхніх посадових осіб у сфері НБ України;

самостійно надавати кваліфіковану оцінку нормативноправовим актам та іншим державно-управлінським рішенням на предмет забезпечення безпеки особи, суспільства та держави;

застосовувати інноваційні технології та інструменти публічного управління та адміністрування для вирішення завдань НБ на загальнодержавному, регіональному, місцевому рівнях;

готувати обгрунтовані пропозиції щодо внесення змін та/або доповнень до чинних законодавчих актів, а також до державних, регіональних та місцевих цільових програм соціально-економічного розвитку, в частині належного урахування безпекових аспектів; 
опрацьовувати проекти управлінських рішень 3 питань НБ та реалізовувати комплекс заходів щодо їхнього ефективного впровадження, компетентно оцінюючи існуючі безпекові виклики та загрози;

забезпечувати кваліфікований експертно-аналітичний супровід діяльності різних суб'єктів державного управління, в частині належного виконання їхніх завдань, функцій та повноважень у сфері НБ;

самостійно формулювати аргументовані пропозиції щодо вдосконалення структури, функцій, повноважень, меж відповідальності органів державної влади, органів місцевого самоврядування, інших суб'єктів забезпечення НБ.

Безперечно, зазначена освітня програма має містити результати навчання 3 питань державного управління у сфері НБ, аналогічні відповідним фаховим компетентностям здобувачів вищої освіти. Можемо запропонувати власну редакцію обов'язкових освітніх компонент магістерської ОПП за спеціальністю 281 ПУА «Державне управління у сфері національної безпеки», яка може бути взята за основу зацікавленим закладом вищої освіти (табл. 2).

Таблиия 2 - Перелік обов'язкових компонент магістерської освітньої програми «Державне управління у сфері національної безпеки»

\begin{tabular}{|c|c|}
\hline $\begin{array}{l}\text { № } \\
\text { 3/II }\end{array}$ & $\begin{array}{c}\text { Компоненти освітньої програми } \\
\text { навчальні дисципліни, практики, кваліфікаційна робота) } \\
\end{array}$ \\
\hline 1. & Теоретичні засади державного управління та національної безпеки \\
\hline 2. & $\begin{array}{l}\text { Стратегічне управління державою в умовах глобальних безпекових } \\
\text { викликів }\end{array}$ \\
\hline 3. & $\begin{array}{l}\text { Правове регулювання (правові засади) міжнародної та національної } \\
\text { безпеки }\end{array}$ \\
\hline 4. & $\begin{array}{l}\text { Інституціональний розвиток (інституиійне забезпечення) державного } \\
\text { управління у сфері національної безпеки України }\end{array}$ \\
\hline 5 . & $\begin{array}{l}\text { Інструменти та технології модернізації державного управління у сфері } \\
\text { національної безпеки }\end{array}$ \\
\hline 6. & $\begin{array}{l}\text { Експертно-аналітичне забезпечення (супровід) управлінської } \\
\text { діяльності у сфері національної безпеки }\end{array}$ \\
\hline 7. & Засади демократичного цивільного контролю над сектором безпеки \\
\hline 8. & Переддипломна практика \\
\hline 9. & Кваліфікаційна робота \\
\hline 10. & Сдиний державний кваліфікаційний іспит \\
\hline
\end{tabular}




\section{Висновки та напрями подальших досліджень.}

Безпекова компетентність здобувачів вищої освіти за вказаною спеціальністю $€$ важливою складовою їхньої професійної підготовки.

Включення закладами вищої освіти у магістерські освітні програми за спеціальністю 281 ПУА обов'язкових компонент (навчальних дисциплін) 3 питань НБ, державного управління у цій сфері, має фрагментарний характер. Аналогічна ситуація спостерігається й щодо вибіркових дисциплін 3 безпекової тематики.

У змісті магістерських програм підготовки публічних управлінців, пропонованих нині в Україні багатьма провайдерами освітніх послуг, розмивається безпекова компонента, яка була досить стійкою та непорушною складовою професійної підготовки управлінських кадрів за спеціальностями галузі знань 1501 «Державне управління» в системі НАДУ.

Відсутність бюджетних магістерських програм 3 питань державного управління у сфері НБ за спеціальністю 281 ПУА, магістерських програм зі спеціальності 256 Національна безпека, свідчать про брак системного підходу до вирішення проблем професійного навчання управлінських кадрів для сфери національної безпеки.

В Україні існує необхідність розробки та впровадження у навчальний процес магістерських програм «Державне управління у сфері національної безпеки» зі спеціальності 281 ПУА, фінансування таких програм за рахунок коштів державного бюджету, а, згодом, і відновлення галузі знань «Державне управління», яка б включала, в тому числі, спеціальність «Державне управління у сфері національної безпеки».

Актуальними напрямами досліджень 3 відповідної тематики $\epsilon$ пошук та обгрунтування концептуальних підходів до змісту та обсягу безпекової компоненти у магістерських програмах зі спеціальності 281 ПУА, розроблення таких програм з питань державного управління у сфері НБ, а також аналіз та синтез перспективного зарубіжного досвіду з цих питань. 


\section{Науковий вісник : Державне управління № 4(10) 2021}

\section{Список використаних джерел}

1. Стратегія національної безпеки України : Указ Президента України від 14 вересн. 2020 p. № 392/2020. URL: https://zakon.rada.gov.ua/laws/show/392/2020 (дата звернення : 05.10.2021).

2. Стратегія реформування державного управління України на 2022-2025 роки : розпорядження Кабінету Міністрів України від 21 липн. 2021 р. № 831-p. URL : https://zakon.rada.gov.ua/laws/show/831-2021-\%D1\%80 (дата звернення : 05.10.2021).

3. Про затвердження переліку галузей знань і спеціальностей, за якими здійснюється підготовка здобувачів вищої освіти : постанова Кабінету Міністрів України від 29 квітн. 2015 p. № 266. URL : https://zakon.rada.gov.ua/laws/show/266-2015-\%D0\%BF (дата звернення : 07.10.2021).

4. Деякі питання реформування системи професійного навчання державних службовців i посадових осіб місцевого самоврядування : постанова Кабінету Міністрів України від 27 вересн. 2016 р. № 674. URL : https://zakon.rada.gov.ua/laws/show/674-2016-\%D0\%BF (Дата звернення: 07.10.2021).

5. Деякі питання реорганізації закладів освіти : розпорядження Кабінету Міністрів України від 24 лют. 2021 p. № 147-p. URL : https://zakon.rada.gov.ua/laws/show/147-2021\%D1\%80\#Техt (дата звернення: 07.10.2021).

6. Власюк О. С. Національна безпека України : еволюція проблем внутрішньої політики : вибр. наук. праці. Київ : НІСД, 2016. 528 с.

7. Горбулін В. П., Качинський А. Б. Засади національної безпеки України : підручник. Київ : Інтертехнологія, 2009. 272 с.

8. Горбулін В. П., Качинський А. Б. Стратегічне планування : вирішення проблем національної безпеки : монографія. Київ : НІСД, 2010. 288 с.

9. Даник Ю. Г., Катков Ю. І., Пічугін М. Ф. Національна безпека : запобігання критичним ситуаціям. Житомир : Рута, 2006. 387 с.

10. Національна безпека : світоглядні та теоретико-методологічні засади : монографія / за заг. ред. О. П. Дзьобаня. Харків : Право, 2021. 776 с.

11. Качинський А. Б. Безпека, загрози і ризик : наукові концепції та математичні моделі. Київ : Нац. Акад. Служб. безп. Укр., 2004. 472 с.

12. Ліпкан В. А. Теорія національної безпеки : підручник. Київ : КНТ, 2009. 631 с.

13. Ситник Г. П. Державне управління національною безпекою України : монографія. Київ : Вид-во НАДУ, 2004. 408 с.

14. Ситник Г. П. Державне управління у сфері національної безпеки (концептуальні та організаційно-правові засади) : підручник. Київ : НАДУ, 2012. 544 с.

15. Глобальна та національна безпека : підручник / Абрамов В. I. та ін.; за заг. ред. Г. П. Ситника. Київ : НАДУ, 2016. 784 с.

16. Теоретико-методологічні засади забезпечення національної безпеки держави у іiі визначальних сферах : монографія / Богданович В. Ю. та ін. Київ : Кий, 2007. 370 с.

17. Семенченко А. І. Методологія стратегічного планування у сфері державного управління забезпеченням національної безпеки України : монографія. К. : НАДУ, 2008. 425 с.

18. Бабурин С. Н. , Дзлиев М. И., Урсул А. Д. Стратегия национальной безопасности России : теоретико-методологические аспекты : монографія. М. : Магистр ; НИЦ Инфра-М, 2014. $512 \mathrm{c}$.

19. Дзлиев М. И., Романович А. Л., Урсул А. Д. Проблемы безопасности : теоретикометодологические аспекты : монография. М. : Изд-во МГУК, 2001. 195 с.

20. Возжеников А. В. Национальная безопасность (теория, политика, стратегия) : монография. М. : НПО Модуль, 2000. 240 с.

21. Марутян Р. Р. Модернізація підготовки фахівців для системи забезпечення національної безпеки України. Держсавне управління та місцеве самоврядування. 2013. Вип. 3 (18). C. 247-255.

22. Марутян Р. Р. Інтелектуально-ресурсне забезпечення державного управління у сфері національної безпеки України: монографія. Київ : ЦП “Компринт”, 2020. 410 с.

23. James D. Ramsay, Irmak Renda-Tanali. Development of Competency-Based Education Standards for Homeland Security Academic Programs. Journal of Homeland Security and Emergency Management. 2018. Published by DeGruyter. September 8, 2018. URL: https://www.degruyter.com/document/doi/10.1515/jhsem-2018-0016/html (дата звернення : 12.10.2021).

24. Навчально-науковий інститут публічного управління та державної служби Київського національного університету імені Тараса Шевченка / Кафедра глобальної та національної безпеки : вебсайт. URL : http://ipacs.knu.ua/?lang=ukr\&tip=dop\&tipn=Page\&page=268 (дата звернення: 10.10.2021). 


\section{Науковий вісник : Державне управління № 4(10) 2021}

25. Про затвердження змін до Переліку напрямів та спеціальностей, за якими здійснюється підготовка фахівців у вищих навчальних закладах за відповідними освітньокваліфікаційними рівнями, затвердженого постановою Кабінету Міністрів України від 24 травн. 1997 р. № 507 : наказ Міністерства освіти і науки України від 05 травн. 2008 р. № 374. URL: https://zakon.rada.gov.ua/laws/show/z0385-08\#Text (дата звернення: 10.10.2021).

26. Сдина державна електронна база з питань освіти / Конкурсні пропозиції. ЄДЕВО : вебсайт. URL : https://vstup.edbo.gov.ua/offers/?qualification=2\&education_base=620\&speciality=281 (дата звернення: 10.10.2021).

27. Про вищу освіту: Закон України від 01 липн. 2014 р. № 1556-VII. URL : https://zakon.rada.gov.ua/laws/show/1556-18 (дата звернення: 12.10.2021).

28. Стандарт вищої освіти за спеціальністю 281 «Публічне управління та адміністрування» галузі знань 28 «Публічне управління та адміністрування» для другого (магістерського) рівня вищої освіти : наказ Міністерства освіти і науки України від 04 серпн. 2020 р. № 1001. URL : https://mon.gov.ua/storage/app/media/vishchaosvita/zatverdzeni\%20standarty/2020/08/05/281 publichne-upravlinnya-ta-administruvannyamagistr.pdf (Дата звернення: 12.10.2021).

\section{References}

1. Ukaz Prezydenta Ukrainy Stratehiia natsionalnoi bezpeky Ukrainy [National Security Strategy of Ukraine] vid 14 veresn. 2020 r. № 392/2020 URL : https://zakon.rada.gov.ua/laws/show/392/2020 [in Ukrainian].

2. Rozporiadzhennia Kabinetu Ministriv Ukrainy Stratehiia reformuvannia derzhavnoho upravlinnia Ukrainy na 2022-2025 roky [Strategy of public administration reform in Ukraine for 2022-2025] vid 21 lypn. 2021 r. № 831-r. URL: https://zakon.rada.gov.ua/laws/show/831-2021-\%D1\%80 [in Ukrainian].

3. Postanova Kabinetu Ministriv Ukrainy Pro zatverdzhennia pereliku haluzei znan i spetsialnostei, za yakymy zdiisniuietsia pidhotovka zdobuvachiv vyshchoi osvity [About the statement of the list of branches of knowledge and specialties on which preparation of applicants of higher education is carried out] vid 29 kvitn. 2015 r. № 266. URL : https://zakon.rada.gov.ua/laws/show/266-2015$\%$ D0\%BF [in Ukrainian].

4. Postanova Kabinetu Ministriv Ukrainy Deiaki pytannia reformuvannia systemy profesiinoho navchannia derzhavnykh sluzhbovtsiv i posadovykh osib mistsevoho samovriaduvannia [Some issues of reforming the system of professional training of civil servants and local government officials] vid 27 veresn. 2016 r. № 674. URL: https://zakon.rada.gov.ua/laws/show/674-2016$\% \mathrm{D} 0 \% \mathrm{BF}$ [in Ukrainian].

5. Rozporiadzhennia Kabinetu Ministriv Ukrainy Deiaki pytannia reorhanizatsii zakladiv osvity [Some issues of reorganization of educational institutions] vid 24 liut. 2021 r. № 147-r. URL: https://zakon.rada.gov.ua/laws/show/147-2021-\%D1\%80\#Text [in Ukrainian].

6. Vlasiuk, O. (2016). Natsionalna bezpeka Ukrainy: evoliutsiia problem vnutrishnoi polityky [National Security of Ukraine: Evolution of Domestic Policy Problems]. Kyiv : NISD [in Ukrainian].

7. Horbulin, V., \& Kachynskyi, A. (2009). Zasady natsionalnoi bezpeky Ukrainy [Principles of Ukraine's national security]. Kyiv : Intertekhnolohiia [in Ukrainian].

8. Horbulin, V., \& Kachynskyi, A. (2010). Stratehichne planuvannia: vyrishennia problem natsionalnoi bezpeky [Strategic planning: solving problems of national security]. Kyiv : NISD [in Ukrainian].

9. Kachynskyi, A. (2004). Bezpeka, zahrozy i ryzyk: naukovi kontseptsii ta matematychni modeli [Security, threats and risk: scientific concepts and mathematical models]. Kyiv: Nats. Akad. Sluzhb. bezp. Ukr. [in Ukrainian].

10. Danyk, Yu., Katkov, Yu., \& Pichuhin, M. (2006). Natsionalna bezpeka: zapobihannia krytychnym sytuatsiiam [National security: prevention of critical situations]. Zhytomyr : Ruta [in Ukrainian].

11. Dzoban, O. P. (Ed.) (2021). Natsionalna bezpeka: svitohliadni ta teoretyko-metodolohichni zasady [National security : worldview, theoretical and methodological principles]. Kharkiv : Pravo [in Ukrainian].

12. Lipkan, V. (2009). Teoriia natsionalnoi bezpeky [Theory of national security]. Kyiv: KNT [in Ukrainian].

13. Sytnyk, H. (2004). Derzhavne upravlinnia natsionalnoiu bezpekoiu Ukrainy [Public administration of National Security in Ukraine]. Kyiv : Vyd-vo NADU [in Ukrainian]. 


\section{Науковий вісник : Державне управління № 4(10) 2021}

14. Sytnyk, H. (2012). Derzhavne upravlinnia u sferi natsionalnoi bezpeky (kontseptualni ta orhanizatsiino-pravovi zasady) [Public administration in the field of national security (conceptual, organizational and legal principles)]. Kyiv : NADU [in Ukrainian].

15. Hlobalna ta natsionalna bezpeka (2016). [Global and national security]. Kyiv: NADU [in Ukrainian].

16. Bohdanovych, Yu., Semenchenko, I., Yehorov, Yu. \& Others (2007). Teoretyko-metodolohichni zasady zabezpechennia natsionalnoi bezpeky derzhavy u yii vyznachalnykh sferakh [Theoretical and methodological principles of ensuring the national security of the state in its defining areas]. Kyiv : Kyi [in Ukrainian].

17. Semenchenko, A. (2008). Metodolohiia stratehichnoho planuvannia u sferi derzhavnoho upravlinnia zabezpechenniam natsionalnoi bezpeky Ukrainy [Methodology of strategic planning in the field of public administration of national security ensurence of Ukraine]. Kyiv : NADU [in Ukrainian].

18. Baburin, S., Dzliev, M., Ursul, A. (2014). Strategija nacional'noj bezopasnosti Rossii : teoretikometodologicheskie aspekty [Russian National Security Strategy: theoretical and methodological aspects]. M. : Magistr ; NIC Infra-M [in Russian].

19. Dzliev, M., Romanovich, A., Ursul, A. (2001). Problemy bezopasnosti: teoretikometodologicheskie aspekty [Security problems: theoretical and methodological aspects]. M. : Izdvo MGUK [in Russian].

20. Vozzhenikov, A. (2000). Nacional'naja bezopasnost' (teorija, politika, strategija) [National security (theory, politics, strategy)]. M. : NPO Modul [in Russian].

21. Marutian, R. (2013). Modernizatsiia pidhotovky fakhivtsiv dlia systemy zabezpechennia natsionalnoi bezpeky Ukrainy [Modernization of training for the national security system of Ukraine]. Derzhavne upravlinnia ta mistseve samovriaduvannia. 3 (18). 247-255 [in Ukrainian].

22. Marutian, R. (2020). Intelektualno-resursne zabezpechennia derzhavnoho upravlinnia u sferi natsionalnoi bezpeky Ukrainy [Intellectual and resource provision of public administration in the field of national security of Ukraine]. Kyiv : TsP «Komprynt» [in Ukrainian].

23. James, D. Ramsay, Irmak, Renda-Tanali. (2018). Development of Competency-Based Education Standards for Homeland Security Academic Programs. Journal of Homeland Security and Emergency Management. 2018. Published by DeGruyter. September 8, 2018. URL : https://www.degruyter.com/document/doi/10.1515/jhsem-2018-0016/html [in English].

24. Navchalno-naukovyi instytut publichnoho upravlinnia ta derzhavnoi sluzhby Kyivskoho natsionalnoho universytetu imeni Tarasa Shevchenka / Kafedra hlobalnoi ta natsionalnoi bezpeky [Educational and Scientific Institute of Public Administration and Civil Service of Taras Shevchenko National University of Kyiv/ Department of Global and National Security]. (2021). URL: http://ipacs.knu.ua/?lang=ukr\&tip=dop\&tipn=Page\&page=268 [in Ukrainian].

25. Nakaz Ministerstva osvity i nauky Ukrainy Pro zatverdzhennia zmin do Pereliku napriamiv ta spetsialnostei, za yakymy zdiisniuietsia pidhotovka fakhivtsiv u vyshchykh navchalnykh zakladakh za vidpovidnymy osvitno-kvalifikatsiinymy rivniamy, zatverdzhenoho postanovoiu Kabinetu Ministriv Ukrainy vid 24 travn. 1997 r. № 507 [About the statement of changes to the List of directions and specialties on which training of experts in higher educational institutions on the corresponding educational and qualification levels is carried out, approved by the resolution of the Cabinet of Ministers of Ukraine from May 24. 1997 № 507] vid 05 travn. 2008 r. № 374. URL : https://zakon.rada.gov.ua/laws/show/z0385-08\#Text [in Ukrainian].

26. Iedyna derzhavna elektronna baza z pytan osvity / Konkursni propozytsii [Unified state electronic database on education / Competitive proposals]. (2021). URL : https://vstup.edbo.gov.ua/offers/?qualification=2\&education_base=620\&speciality=281 [in Ukrainian].

27. Zakon Ukrainy Pro vyshchu osvitu [About higher education] vid 01 lypn. 2014 r. № 1556-VII. URL : https://zakon.rada.gov.ua/laws/show/1556-18 [in Ukrainian].

28. Nakaz Ministerstva osvity i nauky Ukrainy Standart vyshchoi osvity za spetsialnistiu 281 «Publichne upravlinnia ta administruvannia» haluzi znan 28 «Publichne upravlinnia ta administruvannia») dlia druhoho (mahisterskoho) rivnia vyshchoi osvity : vid 04 serpn. $2020 \mathrm{r}$. № 1001. URL : https://mon.gov.ua/storage/app/media/vishchaosvita/zatverdzeni\%20standarty/2020/08/05/281 publichne-upravlinnya-ta-administruvannyamagistr.pdf (: 12.10.2021) [in Ukrainian]. 
Науковий вісник : Державне управління № 4(10) 2021

\title{
SECURITY COMPONENT IN THE STRUCTURE OF PROFESSIONAL COMPETENCE OF HIGHER EDUCATION APPLICANTS BY PUBLIC ADMINISTRATION AND MANAGEMENT
}

\section{Andreiev Serhii}

\begin{abstract}
The article presents the results of a study related to the current state of security educational component in the program of professional training for higher education applicants by the specialty 281 Public Administration (on Master program example) in Ukraine. The author focuses on a crucial need for targeted professional training of government officials competent in the national security issues. The process of developing the specialty Public Administration in the Field of National Security within the field of study 1501 Public administration in 20022015 is considered. The selective analysis of Master program in Public Administration is conducted for some higher education institutions to look through availability of courses (both mandatory and elective) aimed at developing of students' security competence. We propose some recommendations on the list of special (professional, subject) competencies for higher education applicants by Master program in Public Administration in the Field of National Security, as well as the list of mandatory components of the relevant program. Our conclusions are as follows: the inclusion of courses on the national security and public administration in this sphere for Master in Public Administration by the higher education institutions is fragmentary, due to which the security component in these educational programs is blurred; lack of the governmentally funded Master program in 256 National Security, and Master program in Public Administration in the Field of National Security within 281 Public Administration indicate lack of a complex approach to addressing the problems of professional training of managerial staff for the national security sphere. We substantiate the proposal to develop and implement the Master program in Public Administration in the Field of National Security within 281 Public Administration, with its financing from the state budget.
\end{abstract}

Key words: state security, human security, societal security, national security, security competence, higher education, state administration, public administration, public management, competence, professional training. 